\title{
Stefan R. Hauser. “ „...die persische Herrschaft war eigentlich die edelste und beste ...". Die Achaimeniden in deutschen Diskursen im langen neunzehnten Jahrhundert"
}

Reinhardt Pirngruber

\section{(2) OpenEdition}

\section{Journals}

Electronic version

URL: https://journals.openedition.org/abstractairanica/53494

DOI: 10.4000/abstractairanica. 53494

ISSN: 1961-960X

Publisher:

CNRS (UMR 7528 Mondes iraniens et indiens), Éditions de l'IFRI

Electronic reference

Reinhardt Pirngruber, "Stefan R. Hauser. “ „... die persische Herrschaft war eigentlich die edelste und beste ...". Die Achaimeniden in deutschen Diskursen im langen neunzehnten Jahrhundert"', Abstracta Iranica [Online], Volume 42-43 | 2021, document 59, Online since 30 December 2021, connection on 14 December 2022. URL: http://journals.openedition.org/abstractairanica/53494 ; DOI: https://doi.org/ 10.4000/abstractairanica.53494

This text was automatically generated on 14 December 2022.

All rights reserved 


\section{Stefan R. Hauser. “ „...die persische} Herrschaft war eigentlich die edelste und beste ...". Die Achaimeniden in deutschen

\section{Diskursen im langen neunzehnten Jahrhundert"}

Reinhardt Pirngruber

\section{REFERENCES}

Stefan R. Hauser. “ „....die persische Herrschaft war eigentlich die edelste und beste ...“. Die Achaimeniden in deutschen Diskursen im langen neunzehnten Jahrhundert" in R. Rollinger, K. Ruffing, L. Thomas (eds.). Das Weltreich der Perser. Rezeption - Aneignung Verargumentierung. Wiesbaden: Harrassowitz Verlag, 2019, p. 281-304.

1 S. R. Hauser describes the place attributed to Persia in archaeological (Winkelman) and philosophical (Herder, Hegel) discourse in Germany during the 19th century. The Achaemenids were cast into the role of Greece's main adversary, rather than being appreciated in their own right. The Greeks on the other hand were much admired for their national character and alleged spirit of freedom; affinities between contemporary Germany and ancient Greece were regularly invoked. 


\section{AUTHORS}

\section{REINHARDT PIRNGRUBER}

Institut für Orientalistik, Wien 